\title{
Rancang Bangun Sistem Navigasi Indoor Berbasis Integrasi Symbolik Location Model dan Wifi Based Positioning System untuk Studi Kasus pada Gedung Bertingkat
}

\author{
Faris Muhammad Asmawi, Waskitho Wibisono, dan Hudan Studiawan \\ Departemen Teknik Informatika, Fakultas Teknologi Informasi, Institut Teknologi Sepuluh Nopember \\ (ITS) \\ e-mail:waswib@if.its.ac.id
}

\begin{abstract}
Abstrak-Kemajuan teknologi informasi saat ini memudahkan setiap orang dalam kegiatannya masing-masing. Saat ini melakukan navigasi tidak perlu menggunakan selembar peta lagi tetapi cukup mengakses GPS ataupun penyedia jasa navigasi lainnya. Teknologi navigasi saat ini sudah sangat maju untuk navigasi di luar ruangan tetapi untuk di dalam ruangan, belum ada standar khusus dan belum terlalu umum digunakan. Tempat umum di Indonesia, khususnya gedung bertingkat, belum menggunakan teknologi sebagai alat navigasinya dan hanya menggunakan selebaran atau peta denah saja. Saat ini masyarakat sudah banyak yang memiliki smartphone sehingga mudah untuk berbagi atau mencari tempat yang diinginkan. Dalam penelitian ini, Indoor Positioning berbasis Wi-Fi akan digunakan untuk menentukan posisi menggunakan kekuatan sinyal beberapa Wi-Fi yang berbeda dengan algoritma K Nearest Neighbor dan Euclidean Distance. Symbolic Model digunakan untuk memodelkan sebuah gedung bertingkat dan dapat menangani kasus-kasus yang ada dalam memodelkan lokasi, seperti overlap, mengandung dan terhubung. Dari hasil pengujian, pengguna dapat melakukan pencarian posisi dengan tingkat akurasi sebesar $86.66 \%$ dan dapat melakukan navigasi ke setiap lokasi yang ada di Departemen Teknik Informatika.
\end{abstract}

Kata Kunci-Gedung Bertingkat, Indoor Positioning, Navigasi, Symbolic Location Model, Wi-Fi.

\section{PENDAHULUAN}

$\mathrm{K}$ EMAJUAN teknologi informasi saat ini memudahkan setiap orang dalam kegiatannya masing-masing. Saat ini melakukan navigasi tidak perlu menggunakan selembar peta lagi tetapi cukup mengakses GPS ataupun penyedia jasa navigasi lainnya. Teknologi navigasi saat ini sudah sangat maju untuk navigasi di luar ruangan tetapi untuk di dalam ruangan, belum ada standar khusus dan belum terlalu umum digunakan [1]. Tempat umum di Indonesia, khususnya gedung bertingkat, belum menggunakan teknologi sebagai alat navigasinya dan hanya menggunakan selebaran atau peta denah saja. Saat ini masyarakat sudah banyak yang memiliki smartphone sehingga mudah untuk berbagi atau mencari tempat yang diinginkan.

Ketika di dalam gedung bertingkat, kita tidak bisa menggunakan satelit seperti GPS untuk mendapatkan posisi pengunjung. Untuk mendapatkan posisi di dalam ruangan, kekuatan sinyal Wi-Fi akan digunakan sebagai penentu lokasi keberadaan pengunjung. Setiap lokasi yang ada akan memiliki beragam kekuatan sinyal dari Wi-Fi yang berbeda, sehingga setiap lokasi akan unik karena kekuatan sinyal Wi-Fi akan berbeda. Selain menentukan posisi, diperlukan model untuk lokasi-lokasi yang ada sehingga memudahkan pengunjung untuk menentukan posisinya dan melakukan navigasi ke lokasi lainnya. Untuk membuat sistem navigasi gedung bertingkat diperlukan integrasi keduanya, yaitu penentuan posisi dan pemodelan lokasi. Dalam kasus ini, informasi lokasi destinasi berguna bagi pengunjung yang belum pernah memasuki sebuah gedung dan ingin mendapatkan navigasi yang efisien ke tujuannya. Selain membantu pengguna melakukan navigasi di dalam gedung, pengguna juga bisa berbagi lokasinya kepada pengguna lain jika diinginkan.

Dalam makalah ini, Indoor Positioning berbasis Wi-Fi akan digunakan untuk menentukan posisi menggunakan kekuatan sinyal beberapa Wi-Fi yang berbeda. Model lokasi yang digunakan adalah Symbolic Location Model, selain mudah dibaca, model tersebut memiliki kemudahan untuk menentukan posisi terdekat karena model pengelompokannya yang umum [2]. Symbolic Model dapat memodelkan sebuah gedung bertingkat dan dapat menangani kasus-kasus yang ada dalam memodelkan lokasi, seperti overlap, mengandung dan terhubung.

\section{STUDI LITERATUR}

\section{A. Indoor Positioning System}

Indoor positioning system (IPS) adalah sistem pencarian posisi untuk di dalam ruangan yang berbasis context-aware [3]. Context-aware adalah sadar dengan situasi sekitar dan secara otomatis beradaptasi dengan konteks tersebut [4]. Sistem ini menggunakan kekuatan sinyal Wi-Fi yang digunakan sebagai konteks untuk menentukan posisi dari pengguna. Penggunaan sistem pencarian posisi popular seperti 
Global Positioning System (GPS) untuk mencari posisi di dalam ruangan juga kurang efektif karena sinyal satelit tertutup oleh bangunan.

Dalam makalah ini, dibangun sebuah aplikasi yang menggunakan sinyal Wi-Fi untuk mengetahui posisi pengguna ketika berada di dalam ruangan..

\section{B. Algoritma K Nearest Neighbor}

$K$ Nearest Neighbor adalah algoritma yang menyimpan seluruh data yang tersedia dan mengklasifikasikan kasus baru berdasarkan kesamaan dalam perhitungan (seperti fungsi jarak). K Nearest Neighbors atau KNN telah banyak digunakan untuk estimasi statistic dan mengenali pola.

Algoritma ini mengklasifikasikan sebuah kasus dengan melakukan voting mayoritas dari neighbors nya, dimana kasus diberikan pada kelas yang paling mirip diantara tetangganya yang dihitung berdasarkan fungsi jarak. Jika $\mathrm{K}=1$, maka kasusnya cukup memilih kelas dengan tetangga terdekat [5].

Cara memilih nilai $\mathrm{K}$ optimal yang terbaik adalah dengan menginspeksi dahulu data yang ada. Secara umum, nilai $\mathrm{K}$ yang besar menghasilkan data yang akurat karena mengurangi keseluruhan noise tetapi tetap tidak terjaminan. Validasi silang adalah cara lain secara retrospektif untuk menentukan nilai $\mathrm{K}$ yang baik dengan menggunakan dataset yang independen untuk memvalidasi nilai dari K. Dari perhitungan-perhitungan yang pernah dilakukan, nilai optimal dari $\mathrm{K}$ berada pada 3 hingga 10, dimana hasil dari klasifikasi lebih baik dari 1 Nearest Neighbor.

Perhitungan jarak yang digunakan adalah perhitungan jarak Euclidean, dimana hasil akhir perhitungan akan digunakan untuk voting mencari neighbor terdekatnya. Berikut adalah persamaan Euclidean:

$$
\text { EuclideanDist }\left(x_{i}, y_{i}\right)=\sqrt{\sum_{i=1}^{k}\left(x_{i}-y_{i}\right)^{2}}
$$

Pada penelitian ini, (1) digunakan untuk mencari posisi pengguna. $x_{i}$ adalah data kekuatan sinyal Wi-Fi yang telah diinspeksi dan digunakan sebagai acuan dan $y_{i}$ adalah data kekuatan sinyal Wi-Fi saat melakukan pencarian posisi. Hasil dari perhitungan jarak Euclidean akan dipilih yang terendah dan jumlah perhitungan yang akan di voting berdasarkan jumlah K dari K Nearest Neighbor yang akan digunakan.

\section{Symbolic Location Model}

Symbolic location model adalah model yang terdiri dari hierarki dari lokasi simbolik, dimodelkan berdasarkan hubungan spasial "mengandung".

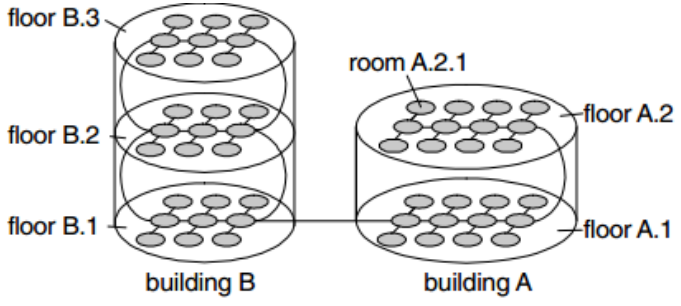

Gambar 1. Model Lokasi Simbolik

Model lokasi simbolik memiliki kemampuan untuk menunjukkan sebuah detail dari model dan melakukan pembagian ke model yang lebih kecil [2]. (a)

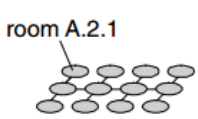

(b)

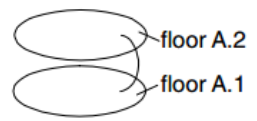

(c)

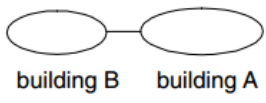

Gambar 2. Tingkat Detil dari Model Lokasi Simbolik

Dalam penerapannya, kita dapat menggunakan untuk mendaftarkan lokasi yang ada sesuai dengan pengelompokannya serta mendaftarkan jarak antara lokasi yang terhubung. Pemodelan lokasi ini mirip dengan graph sehingga algoritma pencarian jarak terdekat dapat dilakukan.

\section{Algoritma Dijkstra}

Algoritma Dijkstra adalah algoritma untuk mencari jarak terpendek dari graph berarah dengan bobot tidak negatif di sisinya. Cara kerja Algoritma dijkstra memakai strategi greedy, dimana pada setiap langkah di pilih sisi dengan bobot terkecil yang menghubungkan sebuah simpul yang sudah terpilih dengan simpul yang sudah terpilih dengan simpul lain yang belum terpilih.

Algoritma Dijkstra membutuhkan parameter tempat asal, tempat tujuan dan jarak dari jalan yang terhubung. Hasil akhir dari algoritma ini adalah jarak terpendek dari tempat asal ke tempat ujuan beserta rutenya.

Pada penelitian ini, algoritma Dijkstra digunakan untuk melakukan navigasi dimana pemodelan lokasi adalah model simbolik yang mirip dengan graph. Pemodelan simbolik memiliki informasi berupa lokasi, hubungan antar lokasi dan jarak hubungan antar lokasi sehingga perhitungan jarak terpendek dapat dilakukan.

\section{ANALISIS DAN PERANCANGAN}

\section{A. Rancangan Sistem}

Aplikasi yang dibuat adalah Wireless Indoor Navigation System yang memiliki kemampuan untuk menentukan posisi pengguna ketika berada di dalam bangunan Jurusan Teknik Informatika ITS dan melakukan navigasi di dalamnya. Hasil akhir dari aplikasi ini adalah menampilkan posisi dari pengguna dan menunjukkan jalan menuju lokasi yang akan dituju pengguna. Aplikasi ini menampilkan lokasi pengguna dengan melakukan scanning posisi pengguna dan menunjukkan lokasi yang ingin dituju ketika melakukan 
navigasi.

Sistem ini dirancang menggunakan server sebagai penyimpan dan pengirim data, client yang merupakan perangkat bergerak sebagai pengambil data. Server merupakan web service dan database server, sedangkan client merupakan modul aplikasi pada smartphone. Client bertugas untuk mengambil data dan mengirim ke server. Server yang kemudian memproses dan mengirim hasil proses kembali ke client. Server bertugas untuk menerima data dan mengirimkan data yang telah diproses kembali ke client.

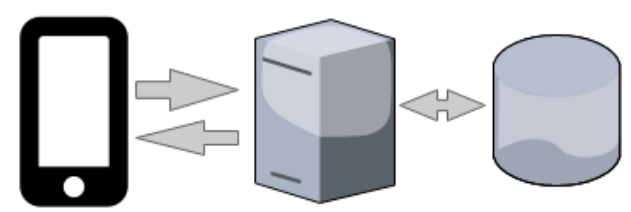

Gambar 3. Arsitektur Umum Sistem

Berdasarkan perancangan arsitektur umum sistem pada Gambar 3, Client smartphone dapat melakukan pencarian posisi dan melakukan navigasi. Smartphone sebagai perangkat bergerak akan mengirimkan data berupa sinyal Wi-Fi beserta mac address dari access point yang telah di scanning pada lokasi tertentu.

Data kekuatan sinyal Wi-Fi dan mac address kemudian di proses oleh server. Sebelum proses, server meminta kepada database data latih dari setiap posisi yang ada. Setelah data hasil scanning dan data latih tersedia, maka dilakukan proses perhitungan dengan pendekatan K Nearest Neighbor.

Pada perhitungan untuk mencari posisi, yaitu perhitungan dengan pendekatan $\mathrm{K}$ Nearest Neighbor, terdapat 2 tahap yaitu menghitung jarak Euclidean antara data hasil scan dengan data latih kemudian dilakukan voting dari hasil perhitungan jaraknya. Voting dilakukan pada hasil perhitungan Euclidean sebanyak nilai $\mathrm{K}$ yang optimal. Hasil akhir dari perhitungan adalah estimasi posisi dari pengguna.

Penggambaran pada peta dilakukan setelah mendapatkan posisi dari hasil perhitungan. Peta kemudian diberi penanda dan akan dikirimkan ke client untuk ditampilkan. Perbedaan antara pencarian posisi dengan navigasi adalah, pencarian posisi hanya menggambarkan posisi dari user sedangkan navigasi akan melakukan perhitungan untuk menentukan jarak terpendek sebelum digambar. Pada proses navigasi, jalan menuju lokasi yang diinginkan dan posisi pengguna akan digambarkan pada peta.

Perhitungan untuk menentukan jarak terpendek dari posisi pengguna menuju lokasi tertentu dilakukan dengan pendekatan algoritma Dijkstra. Perhitungan dilakukan menggunakan data dari pemodelan lokasi simbolik yang telah dilakukan sebelumnya. Model lokasi simbolik mirip dengan graph, yaitu memiliki data lokasi, lokasi yang terhubung dan jarak antar lokasi yang terhubung.

\section{B. Use Case}

Use case sistem merupakan diagram kebutuhan yang menggambarkan fungsionalitas sistem dan aktor-aktornya.
Berdasarkan pada gambar 4, hanya ada satu aktor terlibat yaitu pengguna. Pengguna berinteraksi dengan client untuk menjalankan segala fungsionalitas sistem.

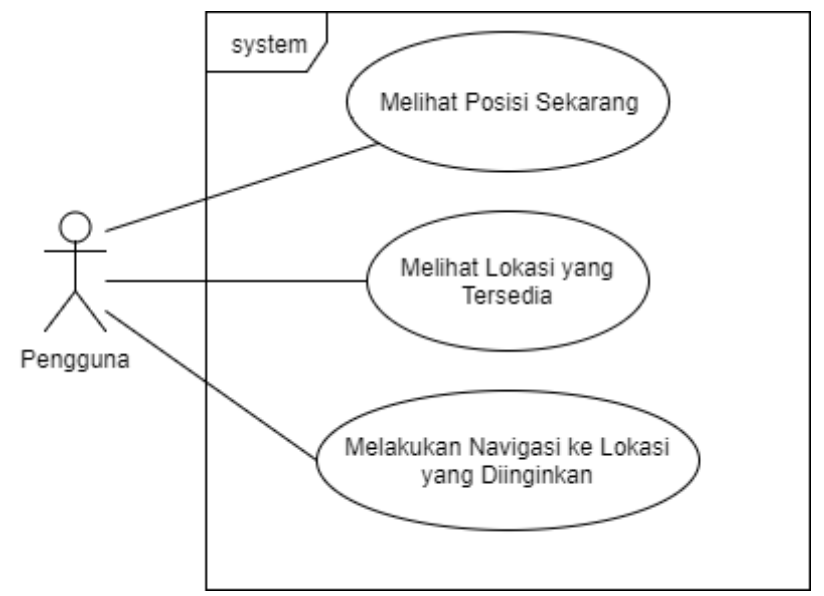

Gambar 4. Diagram Use Case

Use case pertama melihat posisi sekarang, yaitu pengguna dapat melihat posisinya ketika berada di gedung bertingkat. Use case yang kedua adalah melihat lokasi yang tersedia, dimana pengguna dapat melihat lokasi yang tersedia pada gedung dengan menggunakan sistem. Use case yang terakhir adalah melakukan navigasi ke lokasi yang diinginkan. Jika pengguna ingin melakukan navigasi ke lokasi yang ada pada gedung, pengguna dapat menggunakan sistem untuk mendapatkan informasi untuk melakukan navigasi ke lokasi uang diinginkan.

\section{Pemodelan Lokasi}

Lokasi memiliki 2 bagian, yaitu room dan segmen. Room adalah lokasi yang memiliki cakupan lebih besar seperti lantai atau bagian dari sebuah gedung. Segmen adalah lokasi lebih spesifik dari Room yang digunakan untuk mencari posisi yang lebih akurat. Setiap segmen memiliki luas sekitar 3.9 meter x 3.9 meter atau 13 ubin berukuran $30 \mathrm{~cm}$.

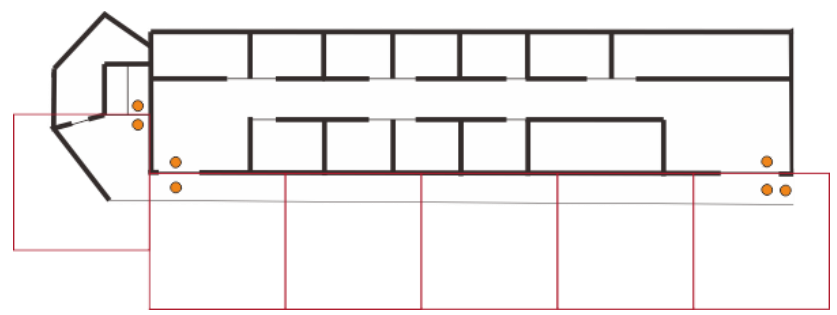

Gambar 5. Pemodelan Lokasi dengan Segmen

Pada gambar 5, Room adalah Jalan Utara Lantai 2 dan persegi dengan garis berwarna merah adalah segmen. Penggunaan model lokasi symbolic akan diterapkan antar Room dan diberi penghubung serta jarak dengan Room lain yang terhubung. Lokasi yang dapat digunakan untuk melakukan navigasi adalah Room dengan minimal terdapat 3 access point atau lebih.

Dalam pemodelan lokasi simbolik, model harus bisa menyimpan lokasi dengan hubungan mengandung dan 
menampilkannya dengan simbol yang dimengerti oleh manusia. Pada penelitian ini, pemodelan yang akan dilakukan adalah menyimpan daftar lokasi yang tersedia, menyimpan lokasi-lokasi yang terhubung pada sebuah lokasi beserta jaraknya dan lokasi yang ada pada peta.

Pada penyimpanan jarak antara lokasi, dapat menggunakan model lokasi untuk menyimpan hubungan antar lokasi untuk dijadikan indeks penunjuk jaraknya. Selain itu perlu pengukuran jarak yang baik untuk menghasilkan navigasi ketika menggunakan model lokasi simbolik sebagai basisnya.

\section{Penentuan Posisi}

Dalam penentuan posisi pengguna, Algoritma $K$ Nearest Neighbor digunakan untuk melakukan klasifikasi perhitungan dari Euclidean Distance dari sinyal yang telah di scanning oleh pengguna.

Perhitungan dilakukan dengan melakukan pembandingan antara kecocokan access point dengan data sampel. Kecocokan dilihat dari mac address milik access point tersebut. Setelah mendapatkan access point yang sesuai dengan hasil scanning, perhitungan jarak Euclidean dilakukan. Setelah melakukan perhitungan jarak makan akan dilanjutkan perhitungan $K$ Nearest Neighbor dan melakukan voting dari hasil perhitungan jarak Euclidean sebanyak nilai $\mathrm{K}$ optimal yang telah dicari sebelumnya.

Tahap ini adalah tahap menyiapkan data latih dengan melakukan scanning data dari setiap segmen dan room yang ada pada lokasi. Tahap ini juga dilakukan inspeksi pada setiap data latih yang telah digunakan sehingga klasifikasi dalam mencari posisi lebih akurat.

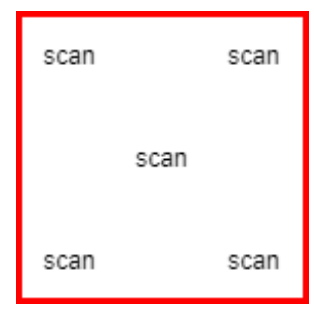

Gambar 6. Posisi dalam Melakukan Scanning pada Segmen

Inspeksi dilakukan untuk melihat apakah nilai dari hasil scan dapat dijadikan acuan untuk perhitungan dalam mencari ruangan dan segmen. Jika data dari hasil scanning terdapat noise atau terjadi kesalahan maka data tersebut dapat dihilangkan atau diganti dengan data baru.

Tahap ini merupakan tahap dimana menentukan nilai $\mathrm{K}$ yang optimal akan menghasilkan posisi yang lebih akurat. Nilai $\mathrm{K}$ optimal dilakukan dengan melakukan perhitungan Euclidean menggunakan data latih dan percobaan dari nilai $\mathrm{K}=1$ hingga $\mathrm{K}=10$. Setelah perhitungan dilakukan maka dilakukan voting hingga menemukan nilai $\mathrm{K}$ yang optimal.

Tahap ini adalah tahap memproses atau melakukan klasifikasi untuk menentukan posisi dari pengguna berdasarkan data scanning yang dikirim oleh pengguna. Setelah menentukan K yang optimal, hasil scanning dengan data latih yang dikumpulkan sebelumnya akan digunakan untuk perhitungan Euclidean dan diklasifikasikan menggunakan K Nearest Neighbor yang menghasilkan posisi pengguna.

Proses yang terjadi dalam penentuan posisi pengguna adalah setelah melakukan perhitungan jarak Euclidean, akan dilakukan pengurutan dan pemotongan dari hasil perhitungan. Setelah diurutkan. Akan dilakukan voting dari neighbor sejumlah K. Jika dalam proses voting, terdapat ruangan yang sama, maka akan dihitung jumlah kemunculan ruangan dan perhitungan jarak Euclideannya akan dihitung rata-ratanya.

Pemilihan lokasi dalam proses voting dilakukan dengan prioritas jumlah kemunculan ruangan terbanyak kemudian rata-rata jarak terkecil apabila terjadi kesamaan dalam kemunculan ruangan terbanyak.

\section{E. Sistem Navigasi dan Integrasi Model dengan Sisten Pencarian Posisi}

Algoritma yang digunakan adalah algoritma Dijkstra dimana algoritma tersebut digunakan untuk pencarian jarak terpendek. Algoritma ini menghitung jarak dari lokasi asal hingga lokasi tujuan hingga menemukan jalan dengan lokasi yang terpendek.

Pada perancangan untuk makalah ini, Integrasi dilakukan agar aplikasi dapat melakukan seluruh fungsi yang akan digunakan. Fungsi pencarian posisi tidak dapat menampilkan lokasinya jika model lokasi tidak ada dan fungsi navigasi tidak dapat dilakukan jika tidak ada perhitungan untuk menentukan posisi awal pengguna.

Integrasi dilakukan dengan menyimpan seluruh data latih setiap segmen pada ruangan dari lokasi yang telah di modelkan oleh pemodelan lokasi simbolik. Pada penentuan posisi di dalam ruangan, hasil klasifikasi dari algoritma $\mathrm{K}$ Nearest Neighbor adalah ruangan yang telah dimodelkan oleh pemodelan simbolik dengan data latih yang telah diintegrasikan.

Untuk navigasi, integrasi digunakan untuk mencari posisi awal pengguna ketika menggunakan aplikasi. Pengguna tidak dapat mencari lokasinya saat itu jika aplikasi tidak memiliki fungsi penentuan posisi. Setelah pengguna mendapatkan posisinya, pengguna dapat melakukan navigasi dari lokasi yang telah di dapatkan menuju lokasi yang dituju. Proses pencarian jarak terpendek untuk mendapatkan jalan dari lokasi awal hinga lokasi tujuan memerlukan model simbolik dengan data jarak antar lokasi

\section{IMPLEMENTASI}

Proses implementasi sistem ini dilakukan setelah melewati proses analisis dan perancangan perangkat lunak. Dalam Bab ini akan dibahas mengenai implementasi dari perancangan yang terdapat dalam perangkat lunak.

\section{A. Basis Data}

Aplikasi ini menggunakan database pada server berbasis MySQL. Implementasi pada struktur basis data meliputi inisiasi tabel room untuk menyimpan daftar ruangan dan location untuk menyimpan data latih dari setiap ruangan. 
Implementasi penyimpanan lokasi simbolik tidak disimpan pada database, tetapi diterapkan pada aplikasi dengan menggunakan array.

\section{B. Penentuan Posisi}

Setelah selesai melakukan inspeksi data dan menentukan nilai $\mathrm{K}$ yang optimal, aplikasi akan melakukan perhitungan untuk menentukan posisi. Perhitungan kemiripan dilakukan dengan algoritma $K$ Nearest Neighbor dengan perhitungan Euclidean Distance.

Setelah scanning, data dikirim kepada server. Pertama kali yang dilakukan adalah menghitung jarak Euclidean dan memotong jumlah perhitungan sebanyak nilai $\mathrm{K}$ optimal yang sudah dicari sebelumnya. Selanjutnya, jika ada room yang sama, akan dilakukan perhitungan tambahan untuk menentukan pilihan ruangan yang lebih akurat dengan menghitung rata-rata dari ruangan tersebut.

Proses selanjutnya adalah dari total room yang ada, dipilih jumlah room terbanyak dengan perhitungan rata-rata paling rendah. Lokasi yang terpilih akan memiliki nilai jarak Euclidean yang terendah dan jika terdapat room yang sama, nilai rata-rata dari roomnya adalah yang paling rendah.

\section{Navigasi}

Implementasi navigasi pada aplikasi ini menggunakan algoritma Dijkstra yang dikembangkan, dimana dalam pencarian jarak diberi batas. Ketika pencarian jarak melebihi batas dari jarak yang sudah ditemukan, maka pencarian tidak akan dilanjutkan. Batas akan berubah jika dalam pencarian jalan, menemukan jalan dengan jarak yang lebih dekat.

\section{Tampilan Aplikasi}

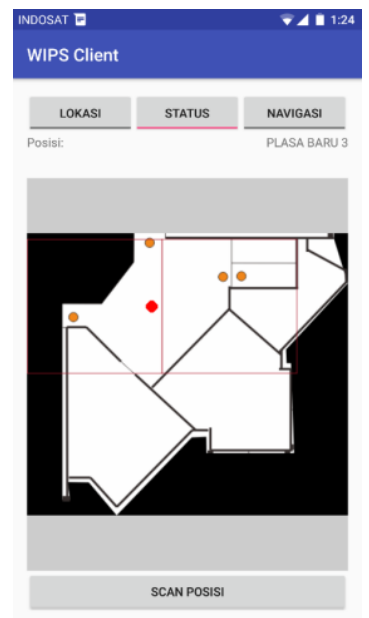

Gambar 7. Tampilan Aplikasi saat Mencari Posisi Pengguna

\section{PENGUJIAN DAN EVALUASI}

Pada bab ini dijelaskan mengenai rangkaian uji coba dan evaluasi yang dilakukan terhadap sistem yang dibuat. Pembahasan yang dipaparkan meliputi lingkungan uji coba, data uji coba, skenario uji coba, hasil uji coba, dan evaluasi.

Lokasi uji coba untuk studi kasus gedung bertingkat adalah jurusan Teknik Informatika Sepuluh Nopember. Lingkungan uji coba untuk penelitian ini adalah smartphone Xiaomi Redmi Note 3 Pro sebagai client dan server berbasis PHP dan mySQL yang di hosting pada hostinger.com.

Berikut adalah hasil dari pengujian fungsionalitas berdasarkan desain use case.

Tabel 1.

Hasil Pengujian Fungsionalitas Aplikasi

\begin{tabular}{cll}
\hline \hline No & \multicolumn{1}{c}{ Use Case } & Hasil \\
\hline 1 & Melihat Posisi & Berhasil \\
2 & $\begin{array}{l}\text { Pengguna Saat Ini } \\
\text { Melihat Lokasi yang }\end{array}$ & Berhasil \\
3 & Tersedia & Belakukan Navigasi \\
\hline \hline
\end{tabular}

Pengujian selanjutnya adalah performa aplikasi dalam melakukan fungsinya. Performa yang diuji adalah tingkat akurasi dari penentuan posisi dan kecepatan dalam memproses fungsionalitas.

Hasil pengujian dari akurasi penentuan posisi pengguna, aplikasi berhasil mendapatkan 26 posisi yang tepat dari 30 percobaan atau tingkat keberhasilan $86.66 \%$. Untuk pengujian kecepatan performa, dalam penentuan posisi, aplikasi dapat memproses dalam waktu rata-rata $28 \mathrm{~ms}$ (milisecond) dan $1 \mathrm{~ms}$ (milisecond) untuk mendapatkan navigasi.

\section{KESIMPULAN}

Berdasarkan hasil uji coba yang telah dilakukan, terdapat beberapa kesimpulan yang bisa diambil, yaitu:

1) Pemodelan lokasi untuk gedung bertingkat dengan model simbolik dapat digunakan. Fitur dari pemodelan seperti lokasi terhubung, lokasi yang mengandung dan jarak antar lokasi dapat dimodelkan.

2) Navigasi dapat menampilkan jalan yang optimal untuk menuju ke lokasi tujuan.

3) Tingkat akurasi $86.66 \%$ dapat diandalkan untuk penggunaan secara umum dengan ruangan yang memiliki access point yang dipasang dengan rapih.

4) Pada uji performa, server dari aplikasi dapat melakukan proses dengan cepat yaitu sekitar 28ms (milisecond) untuk pencarian posisi dan $1 \mathrm{~ms}$ (milisecond) untuk pencarian navigasi. Meskipun ujicoba performa dapat dilakukan dengan cepat, kondisi jaringan dapat mempengaruhi client dalam mengirim data dan mendapatkan respon dari server.

\section{DAFTAR PUSTAKA}

[1] I. Satoh, "A location model for smart environments," Des. Use Smart Environ., vol. 3, no. 2, pp. 158-179, 2007.

[2] A. S. dan J. F. M. A. K. Dey, "UbiComp 2003: Ubiquitous Computing," in the 5th Annual Conference on Ubiquitous Computing, 2003.

[3] R. I. P. Putra, "Rancang Bangun Sistem Pendeteksi Posisi dalam Ruangan Menggunakan Kekuatan Sinyal Wi-Fi dengan Penerapan Algoritma Cluster Filtered KNN," 2013.

[4] S. Loke, Context Aware Pervasive Sytem: Architectures of a New Breed of Applications. New York: Auerbach Pub, 2006.

[5] S. Sayad, "An Introduction to Data Mining: K Nearest Neighbors - 
Classification," 2017. [Online]. Available: http://www.saedsayad.com/k_nearest_neighbors.htm. 